\title{
Mother dough in bread making
}

\section{Beatriz Bot, Hugo Sánchez*, María de la Torre, Carlos Osella}

Instituto de Tecnología de Alimentos, Facultad de Ingeniería Química-Universidad Nacional del Litoral, 1 de Mayo 3250-3000 Santa FeArgentina

\author{
Email address: \\ hsanchez@fiq.unl.edu.ar (H. Sánchez)
}

\section{To cite this article:}

Beatriz Bot, Hugo Sánchez, María de la Torre, Carlos Osella. Mother Dough in Bread Making. Journal of Food and Nutrition Sciences. Vol. 2, No. 2, 2014, pp. 24-29. doi: 10.11648/j.jfns.20140202.11

\begin{abstract}
The objective of this work was the preparation of mother dough and to study the effect produced on bread, besides to look for the kind of bread that best reflects the effect of using sourdough. $\mathrm{pH}$ and acidity were measured to sourdough without replenish during 7 days at $5^{\circ} \mathrm{C}$ and to sourdough with replenishment every 24 hours, during 27 days at $5^{\circ} \mathrm{C}$. Breads were made applying both the French and the pan bread methods. Experts scored the external and internal characteristics of breads. When the sourdough is maintained at $5^{\circ} \mathrm{C}$ and replenished every 24 hours, its stabilization is achieved at the day 10 with a $\mathrm{pH}$ of 4.40 and an acidity of 6.5 mass meq/100 g. By other hand, when the sourdough is maintained at $5^{\circ} \mathrm{C}$ but is not replenished every 24 hours, $\mathrm{pH}$ and acidity are constant up to the day 3 and then a very important change is produced. The addition of $10 \%$ of mother dough improves quality of crumb structure and flavor in the French type bread while there is not an improved quality of the pan bread. Therefore, the French type bread is the kind of bread that best reflects the effect of using mother dough.
\end{abstract}

Keywords: Mother Dough, Wheat Flour, Bread, Baking

\section{Introduction}

Bread is a consumer product that integrates the table of most homes, either to accompany meals or as the only food. The bread making in mold is a complex process in which the dough may consist of flour, water, yeast, sugar, salt and fat, and then it is fermented and baked [1]. By other hand, the French bread is obtained by kneading, fermentation and baking of only flour, water, yeast and salt [2]. When choosing a food, sensory perception is very important, so that the manufacturer always tries to meet the needs of consumers [3]. Therefore, in addition to traditional ingredients, nowadays is added to the preparation, gluten, oxidants, emulsifiers, preservatives, enzymes, fat among other components that are intended for the production of a product more appetizing and of good quality [4,5]. Bread staling, leads to degradation of the overall quality and especially of the flavor, followed by the growth of molds [6]. Therefore, several methods have been proposed to deal with this problem such as the use of chemical additives, application of aseptic technologies or employment of new sourdough starter cultures [7-10]. In making bread, fermentation is a vital step for quality, since it depends on several characteristics of the final product, such as bread volume and crumb's alveoli [11]. The microorganisms responsible for fermentation are yeasts and various factors influencing on their activity are chemicals such as $\mathrm{pH}$, nutrient availability and the presence of substances capable of blocking or inhibiting the fermentation activity. Yeast can be used as commercial biological or natural. Commercial yeast is a pure strain of Saccharomyces cereviceae, obtained by industrial processes and sold as compressed yeast or dehydrated active yeast. Occurs mainly, alcoholic type, slightly acidic, and its action is predictable and reproducible under appropriate conditions of manufacturing [12]. This yeast has been the most studied, and have identified genes responsible for the production of various metabolites of fermentation as the ethyl alcohol [13]. The use of natural yeast is one of the oldest processes in the production of breads. This natural yeast is a heterogeneous population of yeasts and lactic acid bacteria resulting from a fermentation of a flour dough and water $[14,15]$. These lactic acid bacteria are the main responsibilities for producing amino acids that contribute to the flavor of the product [16-21]. The bread flavour is considered as the most important attribute consumer acceptability [22]. Non volatile components provide basic tastes such as sweet, sour, salty, bitter, etc. While volatile compounds, despite being in very low concentrations, contribute to the overall flavour of the bread $[8,10]$. 
Fermentation performed with sourdough is slower and more acidic than that produced with commercial yeast $[23,24]$. The formations of different acids have different effects on the fermentation and baking process, depending on the concentration in which they are. A small amount of lactic acid favours the development of Saccharomyces preventing the growth of other microorganisms and gives a more elastic dough, whereas the acetic acid have a negative effect on the characteristics of gluten, causing a short and stiff dough [25]. It is essential that the amount of acid be in optimal proportions, the lactic/acetic ratio should be $3 / 1$ to provide to the dough acidity greater than that obtained with the use of commercial yeast $[11,25]$. The advantages of using natural yeast with respect to the commercial are: a) better preservation of the product due to the greater acidity of the mass that retards the development of fungi, b) the flavour and aroma accentuated by the formation of volatile organic compounds and aromatic products which are formed during cooking between amino acids and sugars and c) the consumption of bread made with natural yeast brings a nutritional benefit because of the acidic mass makes decrease postprandial glucose response and increase the bioavailability of minerals of bread $[10,26]$.

In this work we assess the preparation of mother dough and its effect on bread quality, besides to look for the kind of bread that best reflects such effect of using sourdough.

\section{Materials and Methods}

\subsection{Materials}

Wheat flour, suitable for industrial bread making, was provided by Molinos Matilde Santa Fe (Argentina) with the following characteristics: $13.5 \%$ moisture, $10.3 \%$ protein (\% Nx5.7), 26.5\% wet gluten, $1.22 \%$ fat, $0.59 \%$ ash. Physical properties at Brabender farinograph were: water absorption $60.0 \%$, development $2.5 \mathrm{~min}$, stability $18 \mathrm{~min}$, and softening 20 Brabender units (BU) and physical properties at Chopin alveograph were: deformation energy (W) 270 Joules $\times 10^{-4}$ and the ratio strength/extensibility (P/L) 1.31. The sourdough (SD) used was prepared through the following steps:

\begin{tabular}{|c|c|c|}
\hline \multirow{3}{*}{ First Step: Initial dough } & $0.250 \mathrm{Kg}$ & Rye flour \\
\hline & $0.300 \mathrm{Kg}$ & Water $\left(35^{\circ} \mathrm{C}\right)$ \\
\hline & $0.005 \mathrm{Kg}$ & Sugar \\
\hline \multicolumn{3}{|c|}{$\begin{array}{l}\text { Mix all ingredients and allowed to stand } 24 \text { hours at room temperature } \\
\left(20-25^{\circ} \mathrm{C}\right) \text {. }\end{array}$} \\
\hline \multirow{3}{*}{$\begin{array}{l}\text { Second Step: First } \\
\text { replenishment }\end{array}$} & $0.555 \mathrm{Kg}$ & Initial dough \\
\hline & $0.500 \mathrm{Kg}$ & Wheat flour \\
\hline & $0.125 \mathrm{Kg}$ & Water $\left(35^{\circ} \mathrm{C}\right)$ \\
\hline \multicolumn{3}{|c|}{$\begin{array}{l}\text { Mix all ingredients and allowed to stand } 12 \text { hours at room temperature } \\
\left(20-25^{\circ} \mathrm{C}\right) \text {. }\end{array}$} \\
\hline \multirow{4}{*}{$\begin{array}{l}\text { Third Step: Second } \\
\text { replenishment }\end{array}$} & $1.150 \mathrm{Kg}$ & First replenishment \\
\hline & $1.150 \mathrm{Kg}$ & Wheat flour \\
\hline & $0.650 \mathrm{Kg}$ & Water $\left(25^{\circ} \mathrm{C}\right)$ \\
\hline & $0.025 \mathrm{Kg}$ & Salt \\
\hline
\end{tabular}

\begin{tabular}{|c|c|c|}
\hline $\begin{array}{l}\text { Mix all ingredients and } \\
\left(20-25^{\circ} \mathrm{C}\right) .\end{array}$ & ed to stand & Irs at room temperature \\
\hline & $3.000 \mathrm{Kg}$ & Second replenishment \\
\hline Fourth Step: Sourdough & $3.000 \mathrm{Kg}$ & Wheat flour \\
\hline (SD) & $1.680 \mathrm{Kg}$ & Water $\left(25^{\circ} \mathrm{C}\right)$ \\
\hline & $0.060 \mathrm{Kg}$ & Salt \\
\hline
\end{tabular}

Mix all ingredients and allowed to stand 8 hours at room temperature $\left(20-25^{\circ} \mathrm{C}\right)$. With this last step, the sourdough is ready to use in bread making and then it is maintained at $5^{\circ} \mathrm{C}$. The replenishment must be made regularly according to the following formulation:

\begin{tabular}{cc}
\hline $1 \mathrm{Kg}$ & Sourdough \\
$1 \mathrm{Kg}$ & Wheat flour \\
$0.560 \mathrm{Kg}$ & Water $\left(25^{\circ} \mathrm{C}\right)$ \\
$0.020 \mathrm{Kg}$ & Salt \\
\hline
\end{tabular}

\subsection{Evaluation of Sourdough}

$\mathrm{pH}$ and acidity were measured to: a) Sourdough (fourth step), without replenish and during 7 days at $5^{\circ} \mathrm{C}$ and b) Sourdough (fourth stage) with replenishment every 24 hours, during 27 days at $5^{\circ} \mathrm{C}$. The analytical technique used was: 10 grams of dough were disaggregating with $5 \mathrm{ml}$ of acetone. Then $95 \mathrm{ml}$ of water were added and $\mathrm{pH}$ measured. Acidity was measured titrating with $0.05 \mathrm{~N}$ sodium hydroxide up to $\mathrm{pH}=8.3$. After five minutes re-add $0.05 \mathrm{~N}$ sodium hydroxide to bring back to $\mathrm{pH}=8.3$. Once stabilized sourdough, organic acids were determined. The analytical methodology used to make this determination was from [27]. The test was conducted on five samples.

\subsection{French Type Bread Making}

Breads were made as in the baking test for French type bread proposed by [28]. The formula contained $300 \mathrm{~g}$ flour (14\% moisture basis), $6 \mathrm{~g}$ yeast, $6 \mathrm{~g} \mathrm{NaCl}$ and $100 \mathrm{mg} / \mathrm{Kg}$ ascorbic acid. Water was added according to farinograph water absorption to obtain equal dough consistency in all cases and was tempered so as to obtain, at the end of kneading, a dough temperature between 24 and $26^{\circ} \mathrm{C}$. Kneading was done in the farinograph at $60 \mathrm{rpm}$ for $15 \mathrm{~min}$. To start kneading, the control flour must be removed in an amount equal to that added with sourdough. After mixing, dough was rounded and bulk fermented at $27^{\circ} \mathrm{C}$ and $80 \%$ relative humidity, controlling the rising with a push-meter, used to measure proofing. In this instrument, $25 \mathrm{~g}$ of dough rise from 12 to $25 \mathrm{~mm}$ during 50-70 $\mathrm{min}$. The apparatus consists of a glass cylinder (75 mm height, $45 \mathrm{~mm}$ i.d.) with a tight-fitting plastic piston that rises during proofing. After proofing, dough was divided into 100 and $200 \mathrm{~g}$ dough pieces, then shaped and proofed (final fermentation) at $27^{\circ} \mathrm{C}$ and $80 \%$ relative humidity, controlling rising from 15 to $45 \mathrm{~mm}$ height with the push-meter. Pieces were baked at $210{ }^{\circ} \mathrm{C}$ for 30 minutes using an electric oven with steam (Ojalvo S.A. Santa Fe, Argentina). 


\subsection{Bread Making in Molds}

Mold bread manufacturing tests were performed according to the following formulation: $300 \mathrm{~g}$ flour $(14 \%$ moisture basis), $15 \mathrm{~g}$ yeast, $6 \mathrm{~g} \mathrm{NaCl}, 18 \mathrm{~g}$ sucrose, $9 \mathrm{~g}$ of shortening with $32^{\circ} \mathrm{C}$ of melting point, $6 \mathrm{~g}$ defatted dry milk and $100 \mathrm{mg} / \mathrm{Kg}$ ascorbic acid. Water was added according to farinograph water absorption to obtain equal dough consistency in all cases and was tempered so as to obtain, at the end of kneading, a dough temperature between 24 and $26^{\circ} \mathrm{C}$. Ten minutes of kneading was done in the farinograph at $60 \mathrm{rpm}$. To start kneading, the control flour must be removed in an amount equal to that added with sourdough. Levels of sourdough used were: 5, 10 and 15\% that means 5, 10 and 15 gr sourdough/100g flour. After mixing, dough was rounded and bulk fermented at $27^{\circ} \mathrm{C}$ and $80 \%$ relative humidity, controlling the rising with a push-meter. The first fermentation ended when the dough doubled its volume. Then, $240 \mathrm{~g}$ of dough portions were laminated, rolled up and put in molds for a second fermentation. The proofing time finished when dough quadruplicated initial volume (15-60 mm push-meter displacement). Baking molds were $5.5 \mathrm{~cm}$ high, $7 \times 17.5 \mathrm{~cm}$ bottom sides and $9 \times 18 \mathrm{~cm}$ top sides. Baking was carried out in the electric oven at $215^{\circ} \mathrm{C}$ during $28 \mathrm{~min}$.

\subsection{Evaluation of Breads}

After one hour the cooled breads were evaluated. Specific volume was determined by triplicate by the method of rapeseed displacement and five trained people scored for external and internal characteristics (total score). According to reference [28], attributes evaluated and maximum scores were: specific volume, $15(5 \mathrm{ml} / \mathrm{g}$ or higher corresponded to the maximum); crust, 15 (colour and thickness); crumb texture, 15 (elasticity and stickiness); crumb colour, 12 (cream white being the highest score); crumb structure, 8 (For French type bread $8=$ excellent, mix of large and small alveoli and $1=$ poor, only small alveoli; inversely for mold type bread $8=$ only small alveoli and 1=mix of large and small alveoli) (Figure 1); flavour 35 (aroma + taste). Total score was qualified as follows: Excellent (90-100), very good (80-89), good (70-79), acceptable (60-69), poor (50-59), very poor (40-49), extremely poor (30-39) [29].

\subsection{Statistical Analysis}

ANOVA was performed followed by the LSD test (least significant difference) to compare means of triplicates, at 95\% confidence.

\section{Results and Discussion}

\subsection{Sourdough}

Figure 2 shows the results obtained in $\mathrm{pH}$ measurement and acidity determination of the sourdough (fourth step) without replenishment.
There is an important decreasing in $\mathrm{pH}$ after the day 3 and also an increasing of the acidity. By other hand, we need to remark that from day 6 we begin to detect an acid smell unpleasant.

Figure 3 shows the results obtained in $\mathrm{pH}$ measurement and acidity determination of the sourdough (fourth step) with replenishment every 24 hours.

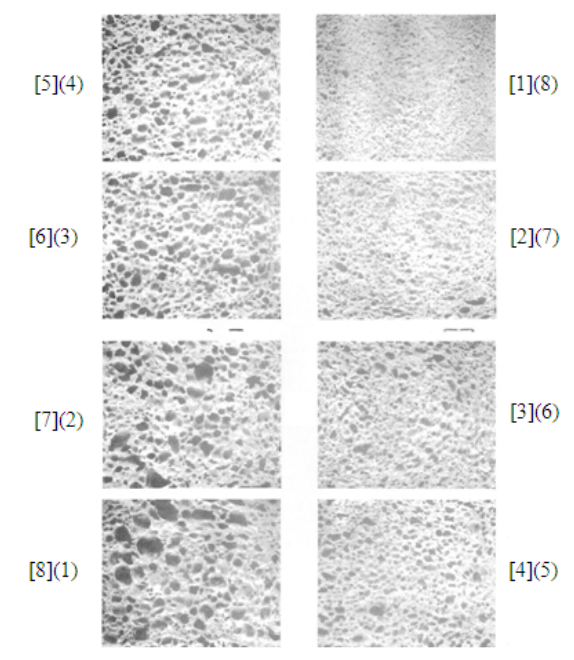

Figure 1. Scheme of Dallman [30]: shows the quality of the crumb structure. The higher the number the best the quality; in brackets for French type bread and in parentheses for mold type bread.

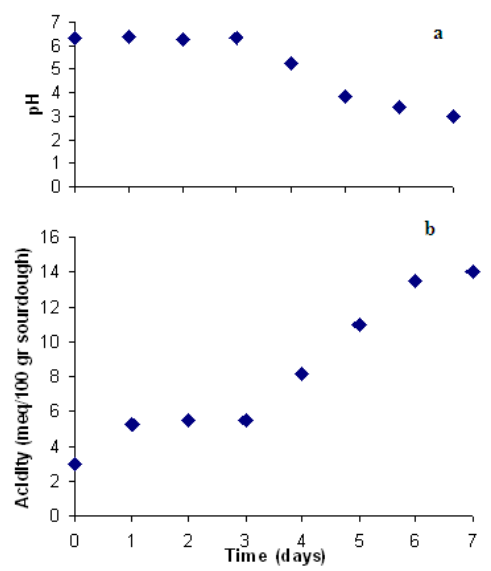

Figure 2. Sourdough (fourth step) without replenishment during 7 days at $5^{\circ} \mathrm{C}$ : (a) pH measurement and (b) acidity determination.

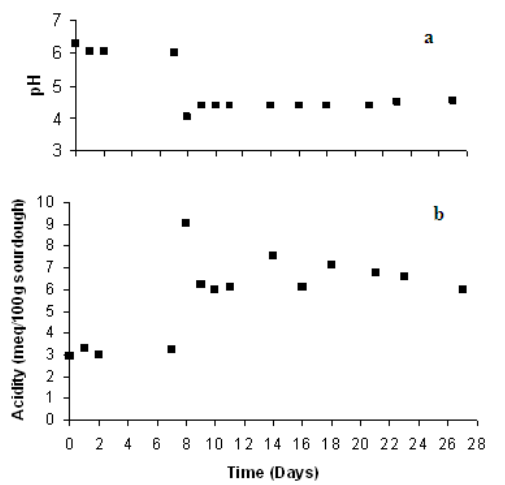

Figure 3. Sourdough (fourth step) with replenishment every 24 hours and during 27 days at $5^{\circ} \mathrm{C}$ : (a) pH measurement and (b) acidity determination. 
As shown in Figure 3, $\mathrm{pH}$ and acidity have changed from the day 7 till the day 10; from there both measurements have constant values. Furthermore, unpleasant aromas were not detected during 27 days because were not reached those unpleasant aromas that are obtained when $\mathrm{pH}=3.1$ and acidity $=13 \mathrm{meq} / 100 \mathrm{~g}$ of dough. Once the dough was stabilized (day 10) the prevailing organic acids were determined. Five samples were analyzed and were found in all of them the presence of lactic acid and acetic acid. Butyric acid was not detected. The ratio of acid lactic/acetic was 2.8, coinciding with Hoseney [25] who states that the optimal ratio of lactic/ acetic should be 3.0, to provide greater acidity than with the use of commercial yeast and so to obtain a better bread quality. Taking account that mother dough was stabilized at day 10 and considering that the unpleasant aromas begin to perceive from day 6 when the mother dough has not replenishment, it was decided to make replenishment after the day 10 , every 3 days. At this moment the sourdough is available for bread making. We must to keep in mind that sourdough amount and acetic acid content of breads are inversely correlated to flavour and specific volume [31].

\subsection{Bread Evaluation}

Table 1 shows the values of specific volume, crumb structure, flavour (aroma + taste) and total score, obtained from French type bread, made with sourdough.

Table 1. Specific volume, crumb structure, flavour and total score of French type bread using sourdough ${ }^{a}$

\begin{tabular}{llllll}
\hline Sourdough (\%) & $\begin{array}{l}\text { Acidity (*) } \\
(\mathbf{m e q} / \mathbf{1 0 0} \mathbf{g} \text { dough) }\end{array}$ & $\begin{array}{l}\text { Specific volume } \\
(\mathbf{m l} / \mathbf{g})\end{array}$ & $\begin{array}{l}\text { Crumb structure } \\
(\mathbf{m a x} . \mathbf{8})\end{array}$ & $\begin{array}{l}\text { Flavour } \\
(\mathbf{m a x} . \mathbf{3 5})\end{array}$ & $\begin{array}{l}\text { Total score } \\
(\mathbf{m a x} . \mathbf{1 0 0})\end{array}$ \\
\hline 0 & 3.0 & $4.30 \mathrm{a}$ & $3.3 \mathrm{c}$ & $25.3 \mathrm{~b}$ & $85.2 \mathrm{a}$ \\
5 & 3.4 & $4.29 \mathrm{a}$ & $3.3 \mathrm{c}$ & $27.0 \mathrm{~b}$ & $78.7 \mathrm{a}$ \\
10 & 3.8 & $3.93 \mathrm{~b}$ & $4.7 \mathrm{~b}$ & $30.7 \mathrm{a}$ & $69.7 \mathrm{~b}$ \\
15 & 4.2 & $3.68 \mathrm{c}$ & $6.0 \mathrm{a}$ & $19.0 \mathrm{c}$ & $60.6 \mathrm{c}$ \\
\hline
\end{tabular}

a Different letters indicate significant differences $(\mathrm{p} \leq 0.05)$

(*) measured at the end of mixing

As seen in Figure 4, when increases the sourdough added to the formulation, decreases the specific volume and the total score of breads, but the crumb structure is improved. The flavour also is improved, but only up to $10 \%$ of substitution, this happens because at higher levels of substitution there is an excess of acidity in the dough. This acidity also produces hydrolysis on the gluten that causes fragility in the network and collapse of alveolus which could be the cause of the decreasing of the specific volume.
Besides, this acidification modifies the rheological properties of the dough, which influences the overall quality of bread [32]. The total score may be affected also by the many compounds obtained from the hydrolysis, which produce a strong aroma and sour taste causing a decrease in the score of the trained panel. Nevertheless a total score of 70 is achieved with a level of substitution of $10 \%$, which means a good qualification.
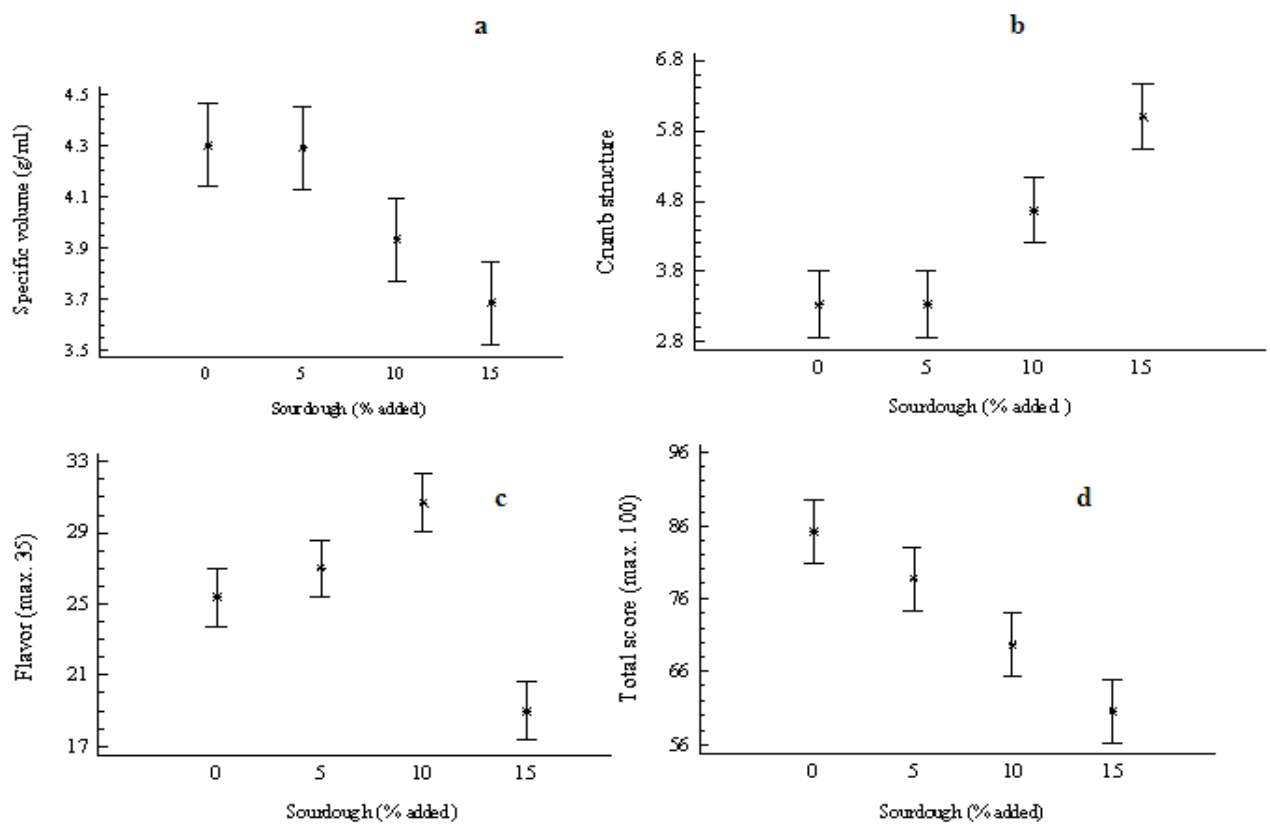

Figure 4. French type bread using sourdough: (a) specific volume (b) crumb structure (c) flavour and (d) total score. 
Table 2. Specific volume, crumb structure, flavour and total score of mold type bread using sourdough.

\begin{tabular}{llllll}
\hline Sourdough (\%) & $\begin{array}{l}\text { Acidity (*) } \\
(\mathbf{m e q} / \mathbf{1 0 0} \mathbf{g} \text { dough) }\end{array}$ & $\begin{array}{l}\text { Specific volume } \\
(\mathbf{m l} / \mathbf{g})\end{array}$ & $\begin{array}{l}\text { Crumb structure } \\
(\mathbf{m a x} 8)\end{array}$ & $\begin{array}{l}\text { Flavour } \\
(\mathbf{m a x} \text { 35) }\end{array}$ & $\begin{array}{l}\text { Total score } \\
(\mathbf{m a x} . \mathbf{1 0 0})\end{array}$ \\
\hline 0 & 2.7 & $5.15 \mathrm{a}$ & $6.7 \mathrm{a}$ & $32.3 \mathrm{a}$ & $87.7 \mathrm{a}$ \\
5 & 3.1 & $4.95 \mathrm{~b}$ & $5.7 \mathrm{ab}$ & $31.0 \mathrm{a}$ & $78.7 \mathrm{~b}$ \\
10 & 3.5 & $4.47 \mathrm{c}$ & $4.7 \mathrm{bc}$ & $27.7 \mathrm{~b}$ & $69.7 \mathrm{c}$ \\
15 & 3.9 & $3.97 \mathrm{~d}$ & $3.7 \mathrm{c}$ & $20.0 \mathrm{c}$ & $60.6 \mathrm{~d}$ \\
\hline
\end{tabular}

Different letters indicate significant differences $(\mathrm{p} \leq 0.05)$

(*) measured at the end of mixing

As seen in Table 2, for mold type bread, the behaviour of the parameters evaluated differ of those obtained for French bread (Table 1). The crumb structure suffers deterioration with the addition of sourdough (figure $5 \mathrm{~b}$ ), with obtaining a crumb non homogeneous which means a lost of quality for this type of bread. In reference to the flavour, a significant lost of quality was obtained for $10 \%$ and $15 \%$ of substitution (figure $5 \mathrm{c}$ ), perhaps because of some interaction of the ingredients that are used in mold type bread that are not used in French type bread.
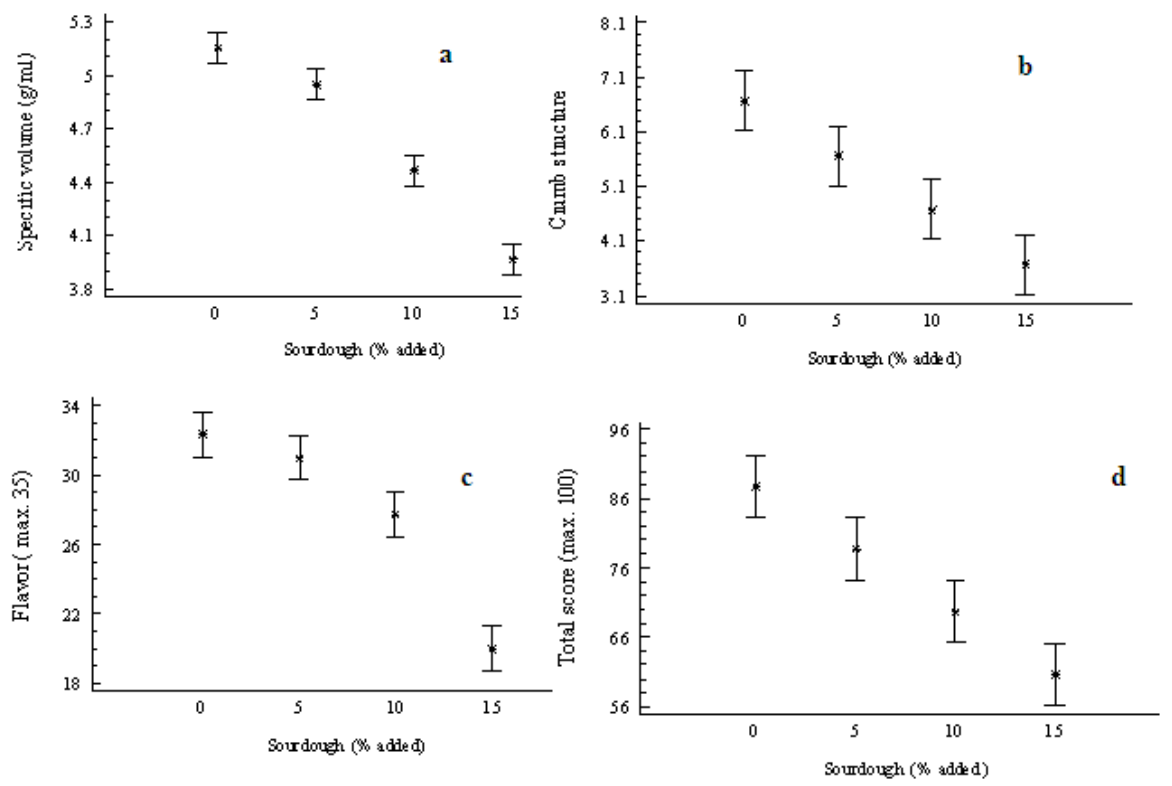

Figure 5. Mold type bread using sourdough: (a) specific volume (b) crumb structure (c) flavour and (d) total score.

\section{Conclusions}

When the sourdough is maintained at $5^{\circ} \mathrm{C}$ and replenished every 24 hours, its stabilization is achieved at the day 10 with a $\mathrm{pH}=4.40$ and an acidity $=6.5$ mass $\mathrm{meq} / 100 \mathrm{~g}$. By other hand, when the sourdough is maintained at $5^{\circ} \mathrm{C}$ but is not replenished every 24 hours, $\mathrm{pH}$ and acidity are constant up to the day 3 and then a very important change is produced. So the sourdough is ready to be used for bread making from the day 10 , when it is stabilized, and it is replenished every three days. The values found for the ratio lactic/acetic, in the stabilized sourdough are the accepted values for working in bread making as is seen in bibliography. The addition of $10 \%$ of mother dough in the formulation has produced an improved quality of crumb structure and flavour in the French type bread while there was not an improved quality of the mold type bread, but in both cases a total score around 70 is achieved, which means be qualified as good. Nevertheless the French type bread is the kind of bread that best reflects the effect of using mother dough.

\section{References}

[1] Swieca, M., Gawlik-Dziki, U., Dziki, D., Baraniak, B. and Czy, J. (2013). The influence of protein flavonoid interactions on protein digestibility in vitro and the antioxidant quality of breads enriched with onion skin. Food Chemistry, 141, 451-458.

[2] Bloksma, A.H. (1978). Rheology and chemistry of dough. In: Wheat chemistry and technology (Edited by Y. Pomeranz). Pp. 523-527. American Association of Cereal Chemists, Inc. St. Paul, MN-USA.

[3] Hersleth, M., Berggren, R., Westad, F. and Martens, M. (2005). Perception of bread: A comparison of consumers and trained assessors. Journal of Food Science, 70, 95-101.

[4] Arendt, E.K., Ryan, L.A.M. and Dal Bello, F. (2007). Impact of sourdough on the texture of bread. Food Microbiology, 24, 165-174. 
[5] Aamodt, A., Magnus, E.M., Hollung, K., Uhlen, A.K. and Færgestad, E. M. (2005). Dough and hearth bread characteristics influenced by protein composition, protein content, DATEM, and their interactions. Journal of Food Science, 70, 214-221.

[6] Minervini, F., Pinto, D., Di Cagno, R., De Angelis, M. and Gobbetti, M. (2011). Scouting the application of sourdough to frozen dough bread technology. Journal of Cereal Science, $54,296-304$.

[7] Komlenić, D.K., Ugarčić-Hardi, Z., Jukić, M., Planinić, M., Bucić-Kojić, A. and Strelec, I. (2010). Wheat dough rheology and bread quality effected by Lactobacillus brevis preferment, dry sourdough and lactic acid addition. International Journal of Food Science and Technology, 45, $1417-1425$.

[8] Plessas, S., Alexopoulos, A., Bekatorou, A., Mantzourani, I., Koutinas, A.A. and Bezirtzoglou, E. (2011). Examination of freshness degradation of sourdough bread made with kefir through monitoring the aroma volatile composition during storage. Food Chemistry, 124, 627-633.

[9] Rizzello, C.G., Cassone, A., Coda, R. and Gobbetti, M. (2011). Antifungal activity of sourdough fermented wheat germ used as an ingredient for bread making. Food Chemistry, 127, 952-959.

[10] Choi, H., Won Kim, Y., Hwang, I., Kim, J. and Yoon, S. (2012). Evaluation of Leuconostoc citreum HO12 and Weissella koreensis HO20 isolated from kimchi as a starter culture for whole wheat sourdough. Food Chemistry, 134, $2208-2216$.

[11] Lönner, C. and Preve-Akesson, K. (2005). Effects of lactic acid bacteria on the properties of sourdough bread. Food Microbiology, 6, 19-35.

[12] Jayaram, V.B., Cuyvers, S., Lagrain, B., Verstrepen, K.J., Delcour, J.A. and Courtin, C.M. (2013). Mapping of Saccharomyces cerevisiae metabolites in fermenting wheat straight-dough reveals succinic acid as pH-determining factor. Food Chemistry, 136, 301-308.

[13] Tanaka, F., Ando, A., Nakamura, T., Takagi, H. and Shima, J. (2006). Functional genomic analysis of commercial baker's yeast during initial stages of model dough-fermentation. Food Microbiology, 23, 717-728.

[14] Aponte, M., Boscaino, F., Sorrentino, A., Coppola, R., Mais, P. and Romano, A. (2013). Volatile compounds and bacterial community dynamics of chestnut-flour-based sourdoughs. Food Chemistry, 141, 2394-2404.

[15] Moroni, A.V., Dal Bello, F., Zannini, E. and Arendt, E.K. (2011). Impact of sourdough on buckwheat flour, batter and bread: Biochemical, rheological and textural insights. Journal of Cereal Science, 54, 195 - 202.

[16] Thiele, C., Gänzle, M.G. and Vogel, R.F. (2002). Contribution of sourdough lactobacilli, yeast, and cereal enzymes to the generation of amino acids in dough relevant for bread flavour. Cereal Chemistry, 79, 45-51.

[17] Mills, D.A. (2004). Fermentation Technology. The lactic acid bacteria genome project. Journal of Food Science, 69, 28-30.

[18] Mcfeeters, R.F. (2004). Fermentation microorganisms and flavour changes in fermented foods. Journal of Food
Science, 69, 35-37.

[19] Katina, K., Heiniö, R.L., Autio, K. and Poutanen, K. (2006). Optimization of sourdough process for improved sensory profile and texture of wheat bread. LWT-Food Science and Technology, 39, 1189-1202.

[20] Herve, R., Valeri, G., Lefebvre, D., Rabier, P., Vayssier, Y. and Fontagne-Faucher, C. (2006). Study of the behaviour of Lactobacillus plantarum and Leuconostoc starters during a complete wheat sourdough breadmaking process. LWTFood Science and Technology, 39, 256-265.

[21] Guerzoni, M.E., Vernocchi, P., Ndagijimana, M., Gianotti, A. and Lanciott, R. (2007). Generation of aroma compounds in sourdough: Effects of stress exposure and lactobacilli-yeasts interactions. Food Microbiology, 24, 139-148.

[22] Heenan, S.P., Dufour, J.P., Hamid, N., Harvey, W. and Delahunty, C.M. (2009). Characterisation of fresh bread flavour: Relationships between sensory characteristics and volatile composition. Food Chemistry, 116, 249-257.

[23] Barber, B., Martínez, J., Cornejo, L. and Benedito, C. (1991) "Efectos de distintas masas madre sobre las características reológicas y fermentativas de la masa panaria". Agroquímica y Tecnología de Alimentos, 31, 512-522.

[24] Meignen, B., Onno, B., Gelinas, P., Infantes, M., Guilois, S. and Cahagnier, B. (2001). Optimization of sourdough fermentation with Lactobacillus brevis and baker's yeast. Food Microbiology, 18, 239-245.

[25] Hoseney, C.R. (1998). Principles of Cereal science and Technology. Pp. 220-273. American Association of Cereal Chemists, Inc. St. Paul, Minnesota, USA.

[26] Lappi, J., Selinheimo, E., Schwab, U., Katina, K., Lehtinen, P., Mykkanen, H., Kolehmainen, M. and Poutanen, K. (2010). Sourdough fermentation of wholemeal wheat bread increases solubility of arabinoxylan and protein and decreases postprandial glucose and insulin responses. Journal of Cereal Science, 51, 152-158.

[27] AACC, (1994). Approved Methods of American Association of Cereal Chemists, 10thed. The Association, St. Paul, MNUSA.

[28] Sánchez, H., Fabre, H. and Mancuello, J. (1983). Essai de panificaction pour le pain francais. Industries de Céréales, $25,29-32$

[29] Tosi, E.A., Re, E.D., Masciarelli, R., Sánchez, H.D., Osella, C.A. and de la Torre, M.A. (2002). Whole and defatted hyperproteic amaranth flours tested as wheat flour supplementation in mold breads. LWT-Food Science and Technology, 35, 472-475.

[30] Dallmann, H. (1969). Die Porentabelle. Verlag Moritz Schäfer. Detmold-Germany.

[31] Novotni, D., Čukelj, N., Smerdel, B. and Ćurić, D. (2013). Quality attributes and firming kinetics of partially baked frozen whole-wheat bread with sourdough. International Journal of Food Science and Technology, 48, 2133-2142.

[32] Clarke, C.I., Schober, T.J., Dockery, P., O'Sullivan, K. and Arendt, E.K. (2004). Wheat sourdough fermentation: Effects of time and acidification on fundamental rheological properties. Cereal Chemistry, 81, 409-417. 